УДК 792.05:7.033:27.5(477)

DOI: 10.31866/2616-759x.2.2018.153237

Бойко Тетяна Антонівна,

кандидат мистецтвознавства, старший науковий співробітник, Київський наиіональний університет культури і мистецтв, Київ, Україна tetiana.boyko@gmail.com ORCID: https://orcid.org/0000-0001-6941-8868

\title{
СЦЕНІЧНА ПРАКТИКА ЙОСИПА ГІРНЯКА В КОНТЕКСТІ БЕРЕЗІЛЬСЬКОЇ СИСТЕМИ ВИХОВАННЯ АКТОРА
}

Мета статті - висвітлити ключові моменти формування універсальної виконавської манери Й. Гірняка й акцентувати на важливості розвитку творчого інтелекту митця; популяризувати постать Й. Гірняка як репрезентанта березільської системи виховання актора серед молодих науковців, практиків сцени, студентів-акторів та ін. Методологія дослідження. Процесові дослідження сприяли аналітичний (осмислено постать Й. Гірняка в межах березільської системи виховання актора), історико-біографічний (проаналізовано суспільно-політичні передумови й естетико-художні вектори того часу, що вплинули на формування творчої особистості митця) та зіставно-типологічний (диференційовано виконавський доробок за принципами існування в ролі) методи. Наукова новизна полягає в розширенні уявлень про процеси формування виконавської манери Й. Гірняка на березільській сцені. Особливу увагу приділено аналізу тих імперативів-настанов Леся Курбаса, що вплинули на розвиток інтелектуальнихі смислотворчих чинників у роботі актора. Висновки. Акторська образна мова Й. Гірняка березільського періоду (1922-1933 рр.) відрізнялася особливою стилістичною гнучкістю, що давало митцеві змогу працювати в різних жанрах, драматургічних реаліях, естетичних системах. Розгляд творчого шляху актора засвідчив, що його сценічна практика відбивала процес виховання березільців на засадах педагогіки Леся Курбаса.

Ключові слова: виконавська манера Йосипа Гірняка; універсальний актор; «перетворення» Леся Курбаса; принцип існування в ролі.

Постановка проблеми. Для сучасного об’єктивного осмислення березільської акторської школи актуальною є думка про те, що до вітчизняного мистецтвознавства має остаточно повернутися й зайняти належні провідні позиції постать Йосипа Гірняка (1895-1989). Адже саме цей актор був не лише ідейним соратником Леся Курбаса, а й утілювачем його художніх інтенцій; він мав унікальну здатність відтворювати зміст режисерської думки, розкривати смислові коди вистави, органічно існувати в будь-яких реаліях сценічної дійсності. Відтак для розуміння моментів опанування акторської професії, особливо розвитку аналітичного мислення й розширення творчого інтелекту, історія Й. Гірняка важлива й для сучасного навчального процесу. Крім високохудожнього відтворення багатьох сценічних образів, принципових для мистецтва 1920-1930-х pp., виконавська практика Й. Гірняка відбивала й технологічний процес виховання акторів-березільців на засадах театральної 
педагогіки Леся Курбаса. Творчі звершення Й. Гірняка на березільському кону не виникали стихійно, завдяки лише природному талантові актора; він, навпаки, крок за кроком, відповідно до оволодіння певними засобами та прийомами, удосконалював майстерність. Акторська практика Й. Гірняка свідчить, що універсального актора можна виховати за допомогою систематичного тренінгу. Однак, щоб стати «ідеальним актором березільського вишколу» (за Р. Черкашиним), Й. Гірнякові довелося пройти певні етапи професійного становлення, апробації різноманітних засобів художньої виразності та принципів акторського існування в ролі.

Аналіз останніх досліджень i публікацій. Загальновідомо, що за радянських часів Й. Гірняк був персоною non grata у вітчизняному мистецтвознавстві. Саме з огляду на цей факт значний внесок у популяризацію його діяльності зробили дослідники української діаспори Б. Бойчук, Л. Дражевська, О. Тарнавський, В. Ткач, Ю. Шевельов та ін. Серед наявних публікацій варто виокремити дві комплексні праці: «В масках епохи» В. Хмурого, Ю. Дивнича й Є. Блакитного (1948) та «Нескорені березільці. Й. Гірняк і О. Добровольська» В. Ревуцького (1985).

Сутність акторських робіт Й. Гірняка в контексті досліджень мистецької діяльності Леся Курбаса вперше окреслено за радянських часів, наприкінці 1960-х - на початку 1970-х рр., у працях Н. Корнієнко, Н. Кузякіної, Л. Танюка. У добу незалежності України, коли змінилася суспільно-політична ситуація, на окремі епізоди творчості Й. Гірняка звертали увагу такі дослідники, як О. Боньковська, Г. Веселовська, І. Волицька, В. Гайдабура, М. Гарбузюк, Г. Дутчак, Н. Срмакова, О. Клековкін, Н. Корнієнко, О. Красильникова, С. Максименко, Н. Чечель та ін.

На сучасному етапі розвитку мистецтвознавства, зберігаючи пієтет до праць попередників, необхідно зазначити, що діяльність Й. Гірняка березільського періоду (1922-1933 рр.) ще потребує певних теоретичних узагальнень та наукових конотацій.

Мета статті - висвітлити ключові моменти формування універсальної виконавської манери Й. Гірняка й акцентувати на важливості розвитку творчого інтелекту митця; популяризувати постать Й. Гірняка як репрезентанта березільської системи виховання актора серед молодих науковців, практиків сцени, студентів-акторів та ін.

Виклад основного матеріалу дослідження. Відомо, що Й. Гірняк вступив до Мистецького об'єднання «Березіль» 1922 р., маючи за плечима семирічний професійний досвід. Тож для конкретизації та з'ясування специфіки виконавської практики Й. Гірняка березільського періоду є потреба звернутися в цій статті й до окремих епізодів біографії митця, що сприяють формуванню цілісного погляду на творчість актора, розкриваючи його сценічний доробок на галицькій сцені, зокрема ті професійні напрацювання, з якими він вступив до МОБу.

Основним джерелом висвітлення Гірнякової біографії $є$ мемуарна книга «Спомини» (1982). У цьому своєрідному амаркорді Й. Гірняк розповідає про головні віхи життя та творчості, характеризує мистецькі й суспільні реалії України першої половини XX ст. Зокрема, з біографії митця відомо, що він народився 14 квітня 1895 p. у галицькому містечку Струсові (нині - 
Теребовлянського району, Тернопільської області). Захоплюватись театром Й. Гірняк почав ще в шкільному віці, бо мав багато вражень і від Гуцульського театру Гната Хоткевича, i від «Тернопільських театральних вечорів» під керівництвом Леся Курбаса, і особливо - від театру товариства «Руська бесіда», на кону якого виступали провідні галицькі актори В. Юрчак, І. Рубчак, К. Рубчакова, А. Осиповичева й ін. Актори «Руської бесіди», за окремими винятками, не мали спеціальної фахової освіти, бо на сцені переважали акторські династії. Потужний творчий імпульс театр «Руської бесіди» отримав за дирекції Йосипа Стадника (1906-1913), який намагався охопити якомога більше сценічних форм і жанрів, виробити певні принципи виконання.

Для молодих галицьких неофітів, до яких долучився і Й. Гірняк, театр був своєрідною лабораторією пізнання світу, чого не могли дати в тих суспільнополітичних умовах інші сфери діяльності. Мистецькі засади, виконавські традиції, багатовекторна стилістична спрямованість «Руської бесіди» суттєво вплинули на формування творчої особистості Й. Гірняка. Упродовж шкільних років він неодноразово брав участь у виставах Й. Стадника як статист, що дало змогу осягнути ази акторської професії, відчути своє покликання.

Професійну акторську діяльність Йосип Гірняк розпочав 1915 р. на кону Стрілецького театру під керівництвом К. Рубчакової, у якому було зібрано переважну більшість акторів театру «Руської бесіди». Стрілецьке командування надало акторам потрібні документи, і вони до 1918 р. гастролювали під його патронатом у Львові та інших містах Галичини, не окупованих російською армією.

Значні сподівання на Гірняковий творчий потенціал покладав актор i режисер Стрілецького театру С. Коханенко, який одразу ж почав доручати новачкові різні ролі - характерні, комедійні, драматичні, оперні, опереткові. Й. Гірняк зіграв Хому у «Ой, не ходи, Грицю» М. Старицького, Антона у «Пошились у дурні» М. Кропивницького, Тиберія Горобця в інсценізації повісті «Вій» М. Гоголя, співав партію російського офіцера Івана в опері «Катерина» М. Аркаса та ін. Жанрове розмаїття репертуару Стрілецького театру зумовило формування універсальної виконавської манери Й. Гірняка. Аби щодня налаштовуватися на кардинально протилежний емоційний стан, від драми до оперети й навпаки, актор повинен був володіти чималим арсеналом засобів художньої виразності і технічних навичок. Емоційного різнобарвного виконання, 3 яким пов'язані юнацькі піднесені враження від гри провідних акторів «Руської бесіди», Й. Гірняк намагався досягати у власній сценічній практиці. Акторському гартуванню новачка неодноразово допомагала присутність на сцені видатних актрис А. Осиповичевої та К. Рубчакової. Партнерство 3 ними було для Й. Гірняка серйозною професійною школою, він перейняв багато навичок 3 декламації, володіння голосом, учився миттєво відтворювати елементи мізансцен, вивчав зовнішні малюнки ролей.

Улітку 1918 р. Стрілецький театр розпався. Згодом на його базі був організований театр товариства «Українська бесіда» за дирекцією В. Коссака. Весною 1919 р. театр «Українська бесіда», віддаляючись від лінії фронту, гастролював у Кам’янці-Подільському, Проскурові, Могилеві-Подільському, а вже на початку 1920 р. у Вінниці приєднався до частини трупи Молодого 
театру. Згодом митці утворили трупу Нового драматичного театру ім. Івана Франка, до складу якої ввійшли А. Бучма, В. Василько, О. Ватуля, П. Долина, О. Добровольська, К. Кошевський, М. Крушельницький, I. Рубак, П. Самійленко, Г. Юра та ін.

3 театром ім. І. Франка актор переїхав до Черкас. За час перебування в складі цього колективу Й. Гірняк зіграв чимало ролей, робота над якими через екстремальні умови існування інколи тривала лише кілька днів. Ним були створені образи багатьох персонажів із п’єс В.Винниченка, зокрема, Штіфа 3 «Чорної Пантери та Білого Медведя», Михася, Ангелка, Середчука із «Гріха», Молодого, Мойша Абрамовича, Віталія Борисовича 3 «Панни Мари». Й. Гірняк брав участь у постановках за творами західноєвропейських та російських класиків, зокрема зіграв Фабриціо, маркіза де Ріппафрата у «Господині заїзду» К. Гольдоні, Бартоло у «Весіллі Фігаро» П. Бомарше, Бобчинського, Добчинського, Осипа у «Ревізорі» М. Гоголя та ін. У Черкасах Й. Гірняк пропрацював 1920-й та половину 1921-го р.,але порозуміння 3 керівником театру Г. Юрою не знайшов.

У 1921 р. частина акторів, а саме: А. Бучма, Й. Гірняк, Л. Гринишак, О. Добровольська, П. Самійленко та ін. вийшли зі складу трупи театру ім. І. Франка й організували театр-студію ім. І. Франка. За короткий період існування Студії було поставлено частину творів 3 репертуару театру ім. І. Франка, а також «Танець життя» Олександра Олеся, «На перші гулі» С. Васильченка, «Камінний господар» Лесі Українки й ін. Після тривалих мандрів у 1922 р. Й. Гірняк з дружиною О. Добровольською виїхав до Києва, щоб вступити до Мистецького об'єднання «Березіль». Разом з ними ціла група акторів була прийнята до 4-ї майстерні МОБу. Цей початковий етап творчості Й. Гірняка, що базувався на кращих виконавських традиціях галицької сцени, був серйозним трампліном для подальшого професійного становлення актора.

Співпраця Й. Гірняка з Лесем Курбасом розпочалася 1923 р. у виставі «Газ» за Г. Кайзером, у якій актор зіграв епізодичну роль Представника влади. 1924 p. актор брав участь у Курбасових виставах «Гайдамаки» за Т. Шевченком та «Макбет» за В. Шекспіром. Також у 1924 р. актор знімався в Одесі у фільмі «Вендетта» (реж. Лесь Курбас), де зіграв роль Попа.

Одними з найбільш вагомих робіт Й. Гірняка у МОБі, що істотно вплинули на його творче становлення, були ролі Джіммі Гіпгінса 3 вистави за однойменним твором Е. Сінклера (1923) й Миколи II з Курбасових вистав «Напередодні» (1925) та «Пролог»(1927). Гірнякові соціальні маски Джіммі та Миколи II відбивали життєві колізії конкретних особистостей і водночас фокусували актуальні суспільно-політичні проблеми.

У Києві, крім роботи з Лесем Курбасом, актор брав участь у виставах інших березільських режисерів. Й. Гірняк працював у різних жанрах, стилістиках, що допомагало йому розвиватись, набиратись досвіду, урізноманітнювати технологічні прийоми акторської праці. 1924 р. Й. Гірняк грав у виставахагітках «Машиноборці» (реж. Ф. Лопатинський) та «Людина-маса» (реж. Г. Ігнатович), обидві за творами Е. Толлера. Ці вистави створювались за принципом масових видовищ, у яких не передбачалося розкриття характеру окремих персонажів, бо всі дійові особи мали відтворювати масовий образ, 
що символізував певне явище сучасності - індустріалізацію, реалії капіталістичного устрою та ін. Наступного, 1925 р.,Й. Гірняк зіграв Голохвостого у виставі «За двома зайцями» за М. Старицким та В. Ярошенком (реж. В. Василько), Кощавку у «Комуні в степах» М. Куліша (реж. П. БерезаКудрицький), Сіра де Беліля у «Жакерії» за П. Меріме (реж. Б. Тягно).

У процесі аналізу творчості Й. Гірняка в МОБі виникає потреба закцентувати увагу на тих чинниках й передумовах, що сприяли розвиткові природних здібностей актора, допомагали формуванню його виконавської манери. Адже Гірнякова сценічна практика була щільно пов’язана i, значною мірою, залежна від мистецьких процесів та пошуків, що відбувались у творчому колективі березільців. Зокрема, на розвиток творчої індивідуальності Й. Гірняка впливали і настанови Леся Курбаса, що спонукали актора замислюватись над характером своєї роботи, читати рекомендовану літературу ${ }^{4}$, i практичні заняття, тренінги. 3 цього приводу дослідниця Н. Срмакова зазначає: «за будьяких умов принциповою була вимога граничної виразності актора-майстра, а постійне фахове самовдосконалення - обов'язковим. В ідеалі всі ці процеси мали відбуватися регулярно. Переважання експресіоністичної, будь-якої іншої художньої ідеології не «скасовувало» жодних вимог до тренінгів, вправ, які могли варіюватися, але ніколи - скасовуватися» (2008, с.21).

Відтак Й. Гірняк разом 3 колегами насамперед учився володіти власним тілом, робити його ключовим інструментом своєї роботи. Цьому сприяли заняття $з$ акробатики і гімнастики, які у МОБі проводили Ф. Лопатинський та П.Береза-Кудрицький, а ритміку й балет викладала В. Чистякова. Ці досить складні фізичні вправи сприяли розкриттю багатьох потенційних можливостей тіла як матеріалу акторської праці.

Окрім тренінгів, значне місце в акторському навчанні березільців посідали заняття зі сценічної мови й основ ритму. Їх у МОБі проводив Й. Кунін, який прагнув навчити драматичного актора досконало володіти голосом за розробленою ним методикою. Також важливими для процесу виховання акторів-березільців були і вправи $з$ мімодрами, тобто етюди на визначену тему, націлені на розвиток спостережливості, уваги, уяви. «У мімодрамах треба було проілюструвати те, що актор заздалегідь намітив у своїй уяві, був здатний зафіксувати у своїй пам’яті та точно повторити» (Гірняк, 1982, с.161).

Систематичні заняття дали змогу вповні розкритися творчому потенціалу Й. Гірняка: він був задіяний майже в усіх конструктивістських постановках МОБу, в яких треба було вправно «літати», стрибати й бігати та «циркізованих» виставах, побудованих на складній еквілібристиці, акробатичних трюках. Паралельно 3 опануванням основ пластики, руху, активно розвивався і загальний кругозір митця, що був позначений широкою ерудицією, аналізом реалій сучасності, осмисленням власних дій на сцені.

Складним i першочерговим завданням актора було осягнення суті Курбасового «перетворення» і вміння працювати за цим особливим принципом побудови сценічної образності, в основі якого лежав «умовний, метафоричний

\footnotetext{
${ }^{4}$ Приміром, у процесі роботи над образом Представника влади у виставі «Газ», Й. Гірняк студіював працю О. Шпенглера «Сутінки Європи», твори Джона Ріда.
} 
спосіб узагальнення дійсності в мистецтві, відображення явищ життя не буквально, а з підкресленням, виділенням в ньому головних, суттєвих рис, того, що прагне акцентувати митець» (Бобошко, 1987, с.99). Для цього акторові потрібно було розвивати ще одну важливу творчу якість - уміння раціонально вирішувати поставлене режисером завдання. I саме в процесі інтелектуальної роботи, глибокого осмислення мало б народжуватися в акторській уяві притаманне лише його психофізиці «перетворення» сценічного образу.

Серйозно посприяло точному, сутнісному розумінню Курбасових інтенцій ще й те, що Й. Гірняк був галичанином. Цю недосліджену проблему спорідненості психологічних типів або типів емоційної поведінки певного регіону, в нашому випадку Галичини, порушила на початку 1990-х pp. Н. Кузякіна. Відомо, що основну частину трупи «Березоля» становили саме галичани: Г. Бабіївна, А. Бучма, Я. Бортник, Й. Гірняк, М. Крушельницький, Ф. Лопатинський, С. Федорцева й ін. На думку Н. Кузякіної, провідні актори легко розуміли Леся Курбаса тому, бо були людьми однієї з ним культури. «Для Курбаса природне зіставлення явищ української культури 3 літературою і театром німецьким, польським. До порівнянь 3 російською культурою він вдається надзвичайно рідко. I актори, які навчалися в гімназіях Галичини і вивчали або чули навколо польську та німецьку мову, розуміли його з півслова: їм не треба було нічого втлумачувати, доводити природність тих чи інших порівнянь, метафор» (Кузякіна, 1993, с.14). Через це й поняття «перетворення», окреслене Лесем Курбасом пунктирно та узагальнено, актори розуміли й докладали багатьох зусиль для його відтворення у певних сценічних образах.

Загальновідомо, що Курбасова ідея «перетворення» базується на синтезі театрального мистецтва 3 науковими розробками у сфері художньої культури, літератури,психології, філософії тощо. Вона «протистоїть естетиці натуралізму, принципам копіювання життєвих форм у мистецтві, пласкому побутописанню, пасивному фотографуванню дійсності» (Курбас, 1988, с.23).

Однак тоді розробки Леся Курбаса ще не набули параметрів театрального методу, бо в багатьох наступних лекціях i виступах переосмислювалися й уточнювалися. Зокрема, тоді ж, у квітні 1925 р., Лесь Курбас у лекції з практики сцени «Про перетворення як один 3 образних засобів розкриття глибокої суті життя» закцентував на деяких моментах «перетворення». «Ми розуміємо, пояснював Курбас, - що наша наука про перетворення $є$ саме тим методом театру, який, будучи цілком реалістичним, абсолютно не буде повторювати того, що діється на вулиці, у певній більшій чи меншій ілюзії дійсності, а, навпаки, пов'язаний саме із намаганням зосередити глядача на ідеї, вкладеній у наш твір, щоб сконцентрувати його увагу; зробити так $з$ даною подією, щоб вона на сцені була виведена у такому вигляді, у такому перетворенні, у такій інакшості, відмінності, у такій новій комбінації, яка саме мусить викликати найбільшу кількість асоціативних процесів» (Курбас, 1988, с.127).

Зокрема, асоціації, що виникали в уяві глядача під час перегляду вистави, були одними із основних важелів образної мови «перетворення». Учні Леся Курбаса - В. Василько, М. Верхацький, П. Масоха, Б. Тягно та ін. - у своїх спогадах наголошували саме на асоціативних моментах як ключових у сприйнятті вистави реципієнтами. Будь-яка інтерпретація мусила викликати 
у глядача органічні його світовідчуттю асоціаційні візії. Сценічна дія «мала пробуджувати уяву глядача, заохотити його не до пасивного споглядання вистави, а до самостійної внутрішньої роботи душі та думки» (Шевченко, 2003, с.50).

Оригінально відтворені Й. Гірняком метафори, алегорії й символи з багатьох вистав МОБу завжди спонукали глядачів до асоціаціативних рефлексій. Приміром, образ гірняківського Миколи II («Напередодні» 1925, «Пролог» 1927) одночасно мав кілька полюсів його сприймання глядачами: як пафосну постать самодержця, як карикатуру на монархічний лад, як маріонетку історії тощо. Тож кожен реципієнт сприймав сценічного Миколу II, керуючись власними асоціаціями стосовно цієї постаті. Із приводу асоціацій, впливу виконавської образної мови Й. Гірняка є потреба закцентувати на тому, що впродовж усієї березільської практики чи не кожен сценічний образ, створений актором, викликав безліч асоціацій, завжди провокував критиків до відшукування тих чи інших порівнянь, аналогій. Приміром, гірняківського Мину Мазайла Й. Шевченко ототожнював 3 «мольєрівським Журденом» (1929), ЧирваКозирнагадував X. Токарю «столипинського мужика» (1930), дід Юхим асоціювався у Ю. Дивнича зі «скобелівським вояком» (1948, с.37).

Творчі здобутки Й.Гірняка в МОБі, репрезентовані низкою сценічних образів (Джіммі Гіггінс, Кукса, Сір де Беліль, Микола II), досягалися завдяки сумлінному навчанню митця всім предметам «березільської науки» та наполегливому прагненню вловити суть режисерських задумів. За час роботи в Києві актор з новачка перетворився на професіонала. Вже у Харкові, куди було переведено «Березіль» 1926 р., Й. Гірняк посів позицію одного із провідних акторів. Ця сторінка виконавської практики митця була, як і київська, тісно пов'язана 3 мистецькими шуканнями Леся Курбаса, який широко використовував надбання світової культури, продукував власні мистецькі ідеї, за допомогою новітніх засобів виразності прагнув розкрити актуальні проблеми тієї епохи.

Дебют Й. Гірняка на харківській сцені відбувся в жовтні 1926 р. у виставі «Золоте черево» за п’єсою Ф. Кроммелінка. Хоча спектакль недовго протримався в репертуарі, виконання Й. Гірняком ролі Мюскара мало лише позитивну оцінку критиків. Згодом Й. Гірняк брав участь у виставі Б. Тягна «Король бавиться» за В. Гюго (1927), де створений ним образ блазня Трібуле органічно поєднував трагічні й гротескові риси. Роком пізніше він створив експресивно виразний образ Мавра у виставі Л. Курбаса і Я. Бортника «Змова Фієска в Генуї» за Ф. Шіллером (1928).

На цьому етапі, виконавська манера Й. Гірняка повністю характеризувалася синтетичністю й універсальністю, актор активно застосовував напрацьовані навички в різножанрових виставах: від трагедії до оперети, від комедії до драми. Окрім створення характерних, гротесково-експресивних сценічних образів, Й. Гірняк грав і комедійні ролі, філігранно володів прийомами сценічної маски, зокрема рисами масок commedia dell'arte актор наділив ексцентричних персонажів Пу-Ба (оперета «Мікадо» за В. Гілбертом-А. Салліваном, 1927) та Ляща (ревю «Алло, на хвилі 477» О. Вишні, М. Йогансена, М. Хвильового, 1929). Гостро актуальні Гірнякові сценічні образи Мини Мазайла («Мина 
Мазайло» М. Куліша, 1929), Чирви-Козиря («Диктатура» I. Микитенка, 1930), Зброжека («Маклена Граса» М. Куліша, 1933) стали і апогеєм творчості митця, і значними здобутками вітчизняного акторського мистецтва 1920-1930-х pp.

Незважаючи на тогочасний ідеологічний тиск, мистецькі, творчі ідеали для Леся Курбаса завжди були важливішими за політичні. Режисер передусім захоплювався процесами формотворення власного, на той час «філософського» за суттю, театру. Утім, однією 3 ціннісних орієнтацій Курбасової творчої команди була художньо-естетична протидія тоталітарному режимові. Мистецтво актора у процесі цієї «завуальованої» протидії відігравало ключову роль, бо особливо промовисто загрозлива суть тоталітаризму відбилася саме в долях персонажів-сучасників, більшість 3 яких були майстерно зіграні Й. Гірняком.

Отже, Гірнякове професійне зростання було цілком залежним від функціонування «мистецького організму» «Березоля». Однак, у жовтні 1933 р., після усунення Леся Курбаса 3 посади керівника театру, усі поставлені ним спектаклі були зняті з репертуару. У Й. Гірняка залишились тільки три ролі: Котя в «Кадрах» I. Микитенка (1931), Кручек у «Плацдармі» Мирослава Ірчана (1932) та Бухта в «Загибелі ескадри» О. Корнійчука (1933). 26 грудня 1933 р. березільський період творчості Й. Гірняка закінчився; його, як однодумця Леся Курбаса, також було заарештовано.

Наукова новизна полягає в розширенні уявлень про процеси формування виконавської манери Й. Гірняка на березільській сцені. Особливу увагу приділено аналізу тих імперативів-настанов Леся Курбаса, що вплинули на розвиток інтелектуальних і смислотворчих чинників у роботі актора над сценічними образами.

Висновки. Творчі здобутки актора на березільській сцені впродовж 1922-1933 pp. не могли б відбутися без систематичного вдосконалення фахових навичок. Його акторська образна мова відрізнялася особливою стилістичною гнучкістю, що давало митцеві змогу працювати в різних жанрах, драматургічних реаліях, естетичних системах. Відповідно, спектр засобів художньої виразності для створення сценічних образів був доволі розмаїтим. Саме в глибинних сполуках духу й думки, в одночасному використанні ресурсів свідомого й підсвідомого була прихована таїна сценічних метаморфоз Й. Гірняка.

Розгляд творчого шляху актора засвідчив, що формування виконавської манери митця відбулося на кону «Березоля», а його сценічна практика відбивала процес виховання березільських митців на засадах театральної педагогіки Леся Курбаса.

\section{Список посилань}

Бобошко, Ю.М., 1987. Режисер Лесь Курбас. Київ: Мистецтво.

Гірняк, Й., 1982. Спомини. Нью-Йорк: Сучасність.

Єрмакова, Н., 2008. Актор з погляду педагогіки : (із практики Мистецького об’єднання «Березіль»). Український театр, 2, с.21-24.

Кузякіна, Н., 1993. Галицький актор: необхідні творчі силуети. Український театр, 5, c.13-14. 
Курбас, Л., 1988. Березіль : із творчої спадщини. Київ: Дніпро.

Курбас, Л., 1988. Статьи и воспоминания о Лесе Курбасе. Литературное наследие. Москва: Искусство.

Токар, Х., 1930. Велика перемога «Березоля» : Від побутових сцен - до патетичної героїки. Робітнича газета Пролетар, 3 черв.

Хмурий, В., Дивнич, Ю. та Блакитний, Є., 1948. В масках епохи : Йосип Гірняк. Мюнхен:Україна.

Шевченко, Й., 1929. «Мина Мазайло». Робітнича газета Пролетар, 21 квіт.

Шевченко, Н., 2003. «Розумний арлекін» - між храмом і площею : (до науки акторського перетворення). Аркадіа, 1, с.49-52.

\section{References}

Boboshko, Yu.M., 1987. Rezhyser Les Kurbas [Directed by Les Kurbas]. Kyiv: Mystetstvo. Hirniak, Y., 1982. Spomyny [Remembers]. New York: Suchasnist.

Yermakova, N., 2008. Aktor z pohliadu pedahohiky : (iz praktyky Mystetskoho ob’iednannia «Berezil») [The actor from the point of view of pedagogy: (from the practice of the Art Association «Berezil»)]. Ukrainskyi teatr, 2, p.21-24.

Kuziakina, N., 1993. Halytskyi aktor: neobkhidni tvorchi syluety [Galician actor: the necessary creative silhouettes]. Ukrainskyi teatr, 5, p.13-14.

Kurbas, L., 1988. Berezil: iz tvorchoi spadshchyny [Berezil : from the creative heritage]. Kyiv: Dnipro.

Kurbas, L., 1988. Stati i vospominaniya o Lese Kurbase. Literaturnoe nasledie [Articles and memoirs about Lesbas Kurbas. Literary heritage]. Moscow: Iskusstvo.

Tokar, Kh., 1930. Velyka peremoha «Berezolia» : Vid pobutovykh stsen - do patetychnoi heroiky [Great victory «Berezol»: From domestic scenes - to the pathetic hero]. Robitnycha hazeta Proletar, 3 June.

Khmuryi, V., Dyvnych, Yu. and Blakytnyi, Ye., 1948. V maskakh epokhy : Yosyp Hirniak [In masks of the era: Joseph Girnyak]. Miunkhen: Ukraina.

Shevchenko, Y., 1929. «Myna Mazailo» [«Mina Mazailo»]. Robitnycha hazeta Proletar, 21 April.

Shevchenko, N., 2003. «Rozumnyi arlekin» - mizh khramom i ploshcheiu : (do nauky aktorskoho peretvorennia) [«Intelligent Harlequin» - between the temple and the area: (to the science of acting transformation)]. Arkadia, 1, p.49-52.

(ㄷ) Бойко Т.А., 2018 


\begin{abstract}
Boiko Tetiana, PhD in History of Art, Senior Research Fellow, Kyiv National University of Culture and Art, Kyiv, Ukraine

\section{YOSYP HIRNIAK'S STAGE PRACTICE IN THE BEREZILIAN SYSTEM CONTEXT IN AN ACTOR EDUCATION}

The purpose of the article is to highlight the key moments in the universal performance manner formation by Y. Hirniak and to emphasize the importance of the artist's the creative intelligence development, to popularize the Hirniak figure as a representative in the actor education Berezilian system among young scientists, scene practitioners, student-actors, etc. Research methodology. The process researches have been carried out by an analytical (Y. Hirniak meaningful figure within the actor education Berezil system), historical and biographical (analyzed socio-political preconditions and aesthetic and artistic vectors at that time which influenced on the artist creative personality formation) and comparativetypological (differentiated performer advances on the existence in a role principles) methods. The scientific novelty consists in expanding the notions about the formation processes in the Y. Hirnyak on the Berylslav stage performing manners. Particular attention is paid to the those imperatives-guidelines Les Kurbas analysis, which influenced on the intellectual and cognitive factors development in the actor's work. Conclusions. The acting language by Y. Hirniak in the Berezil period (1922-1933) has been characterized by a special stylistic flexibility that allowed the artist to work in different genres, dramatic realities, and aesthetic systems. Consideration of the actor's creative path has shown that his stage practice reflected the educational process the bridges on the theatrical pedagogy Les Kurbas principles.

Key words: Joseph Hirniak acting style; universal actor; Les Kurbas «transformation»; existence in a role principle.
\end{abstract}


Бойко Татьяна Антоновна, кандидат искусствоведения, старший научнылй сотрудник, Киевский национальный университет культуры и искусств, Киев, Украина

\section{СЦЕНИЧЕСКАЯ ПРАКТИКА ЙОСИПА ГИРНЯКА В КОНТЕКСТЕ БЕРЕЗИЛЬСКОЙ СИСТЕМЫ ВОСПИТАНИЯ АКТЕРА}

Цель статьи - осветить ключевые моменты формирования универсальной манеры исполнения Й. Гирняка и акцентировать важность развития творческого интеллекта актера; популяризировать личность Й. Гирняка как репрезентанта березильской системы воспитания актера среди молодых ученых, практиков сцены, студентов-актеров и др. Методология исследования. Процессу исследования способствовали аналитический (осмысленно творчество Й. Гирняка в рамках березильской системы воспитания актера), историко-биографический (проанализированы общественно-политические предпосылки и эстетико-художественные векторы того времени, которые повлияли на формирование творческой личности творца) и сопоставимо-типологический (дифференцированно его исполнительское наследие по принципам существования в роли) методы. Научная новизна заключается в расширении представлений о процессах формирования творческой манеры Й. Гирняка на березильской сцене. Особое внимание сосредоточено на анализе тех императивов-наставлений Леся Курбаса, которые повлияли на развитие интеллектуальных и смыслообразующих факторов в работе актера. Выводы. Актерская образная речь Й. Гирняка березильского периода (1922-1933 гг.) отличалась особенной стилистической гибкостью, которая позволяла исполнителю работать в разных жанрах, драматургических реалиях, эстетических системах. Анализ творческого пути актера показал, что его сценическая практика отображала процесс воспитания березильцев на основе театральной педагогики Леся Курбаса.

Ключевые слова: манера исполнения Йосипа Гирняка; универсальный актер; «превращение» Леся Курбаса; принцип существования в роли. 